\title{
Postherpetic Pruritus: A Potential Complication of Herpes Zoster Virus Infection
}

\author{
Shahzeb Hassan ${ }^{1}$, Philip R. Cohen ${ }^{2}$ \\ 1. Dermatology, Northwestern University Feinberg School of Medicine, Chicago, USA 2. Dermatology, San Diego Family \\ Dermatology, San Diego, USA
}

Corresponding author: Shahzeb Hassan, shahzeb.hassan@northwestern.edu

\begin{abstract}
Postherpetic pruritus is an uncommon adverse sequela of Varicella zoster infection. It can present with or without prior postherpetic neuralgia. A 57-year-old woman who developed persistent postherpetic pruritus following a Varicella zoster infection, affecting the skin between her right thoracic fifth to eighth dermatomes is described; she did not have postherpetic neuralgia. Her condition did not improve with systemic antiviral or gabapentin treatment; however, nine years later, she exhibited significant relief after two months of acyclovir $800 \mathrm{mg}$ five times daily. In summary, postherpetic pruritus is a potential complication that can occur alone or in combination with postherpetic neuralgia. Some patients with postherpetic pruritus have a treatment-refractory disease. However, other patients respond to gabapentin; yet, long-term interventions may be necessary for persistent pruritus. Our patient's pruritus significantly improved after restarting systemic antiviral therapy.
\end{abstract}

Categories: Dermatology, Infectious Disease

Keywords: chicken, herpes, itch, pox, pruritus, varicella, zoster

\section{Introduction}

Herpes zoster can result in temporary or permanent postherpetic neuralgia [1]. Postherpetic pruritus is another adverse event that can occur alone or in combination with postherpetic neuralgia [2]. A woman with postherpetic pruritus, who does not have postherpetic neuralgia, is described and the features of this uncommon condition are reviewed.

\section{Case Presentation}

A 57-year-old African American woman presented with itching on her right side in 2019. The itching began in 2010 following an episode of varicella zoster virus infection that affected the skin between her fifth to eighth right thoracic dermatomes. Her Herpes zoster infection was treated with acyclovir ( $800 \mathrm{mg}$, five times a day) for 10 days. She did not experience any pain or postherpetic neuralgia. However, shortly after the blisters resolved, the affected area became pruritic; in addition, she also noted that exposure to cold

Received 08/26/2019

Review began 08/26/2019 Review ended 09/09/2019 Published 09/16/2019

(c) Copyright 2019

Hassan et al. This is an open access article distributed under the terms of the Creative Commons Attribution License CC-BY 3.0., which permits unrestricted use, distribution, and reproduction in any medium, provided the original author and source are credited. temperature made the itch worse.

Her past medical history is significant for cervical cancer, diabetes mellitus (type 2), scleroderma, and systemic lupus erythematosus. Previously, she also had culture-confirmed Varicella zoster virus infections not only in 1999 affecting her seventh to eighth right cervical dermatomes (right hand and fourth finger) but also in 2002 affecting her sixth to seventh right cervical dermatomes (right arm). She has arthritic joint pains and is currently receiving gabapentin, hydroxychloroquine, and prednisone each day.

Cutaneous examination was performed. She had pruritus originating on her right mid-back that extended to involve her right flank and right abdomen. The distribution of her pruritus involved the skin between her right fifth to eighth thoracic dermatomes; excoriations were also present in the affected area on her right side (Figure 1). 


\section{Cureus}

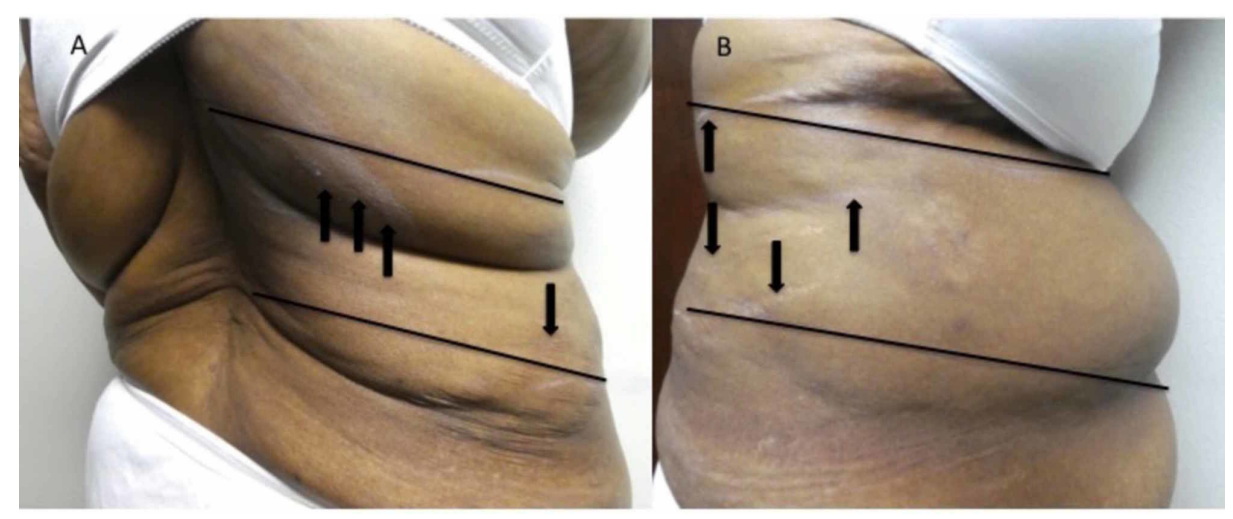

FIGURE 1: Postherpetic pruritus extending from the middle of the back to the abdomen on the right side of a 57-year-old woman

Pruritus is experienced in a region of skin involving the back (A), flank ( $A$ and $B$ ), and abdomen (B) from the right fifth to eighth thoracic dermatomes (between the black lines). Numerous excoriations (black arrows) result from her scratching the pruritic area.

She also had nine hyperpigmented dermal nodules, ranging in size from five to eight millimeters in diameter. They were located on her left arm (three nodules; Figure 2), left abdomen (two nodules), left buttock, left dorsal foot, left hip and right lower back. When the skin adjacent to the nodule was squeezed between the index finger and the thumb, a positive dimple sign - demonstrated by depression of the dermal nodule - would occur. 


\section{Cureus}

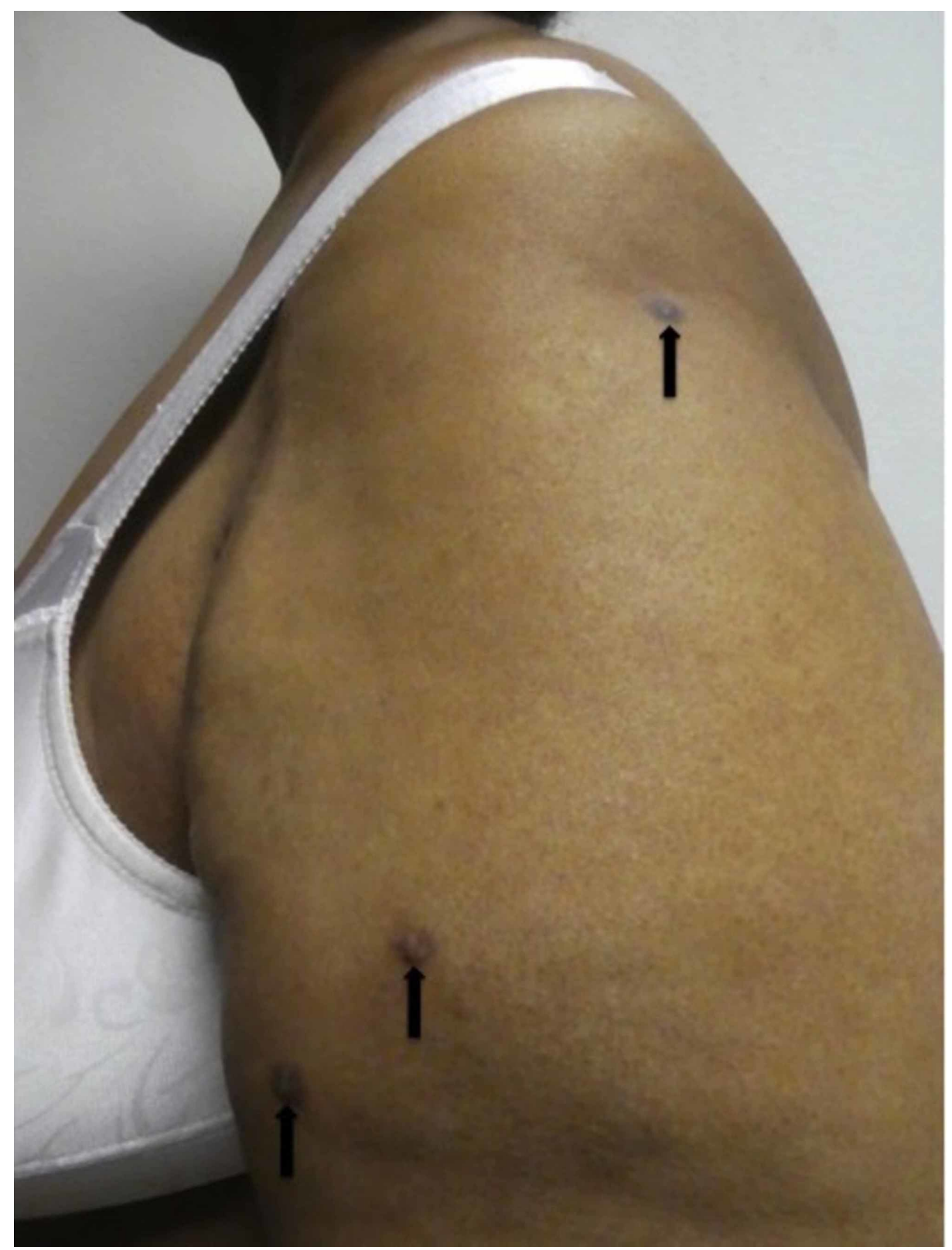

FIGURE 2: Dermatofibromas on the left arm of 57-year-old woman with postherpetic pruritus

Dermatofibromas, presenting as three hyperpigmented dermal nodules (black arrows), are present on the left arm of a woman with systemic lupus erythematous who is being treated with prednisone.

Correlation of her medical history and clinical presentation established the diagnosis of postherpetic pruritus. She also had multiple dermatofibromas on her body and extremities.

She was already receiving gabapentin (600 mg, three times a day), hydroxychloroquine (200 $\mathrm{mg}$, twice daily), and prednisone ( $2.5 \mathrm{mg}$, once daily). Hydroxyzine ( $25 \mathrm{mg}$, three times a day) initially provided temporary relief of her pruritus. Acyclovir ( $800 \mathrm{mg}$, five times a day) was also started. There was a significant improvement of her pruritus at her follow up visit eight weeks later. She continued antiviral therapy.

\section{Discussion}

Herpes zoster is caused by reactivation of the Varicella zoster virus in sensory ganglia. Varicella zoster infection has several potential complications including secondary bacterial infections and postherpetic neuralgia. In addition, some patients develop postherpetic pruritus (which has also been referred to as postherpetic itch) [3]. 
Postherpetic pruritus is characterized by chronic and persistent itching in dermatomes previously affected by herpes zoster. A study of 100 patients with postherpetic neuralgia found that 53 of these patients also experienced postherpetic pruritus. The development of postherpetic pruritus was more frequent amongst the individuals who experienced facial herpes zoster infection [2]. Although postherpetic pruritus most commonly occurred in patients who also had postherpetic neuralgia, some of the affected individuals did not have prior or concurrent postherpetic neuralgia; however, the incidence of postherpetic pruritus in the absence of postherpetic neuralgia remains to be determined [4-6].

The pathogenesis of postherpetic pruritus remains to be established. Varicella zoster infection may have an effect on central itch-specific neurons [4]. Nonetheless, the co-occurrence of pain and itching is thought to involve reduced subepidermal nerve fiber density in postherpetic neuralgia [7].

It may be postulated that the location of postherpetic pruritus is related to a site of immune dysregulation caused by the previous skin damage. Essentially, an immunocompromised cutaneous district is created by the Varicella zoster infection. Subsequently, the pruritus develops in the dermatomal distribution of the prior viral infection [8-11].

The onset of postherpetic pruritus is variable. It can occur immediately following the resolution of blisters. Alternatively, it can begin several weeks after the herpes zoster infection resolves [2].

The severity of postherpetic pruritus varies. Similar to our patient, excoriations - secondary to scratching in the affected dermatomes - may be present.

The treatment of postherpetic pruritus may be complex since neuropathic itch may not respond to antihistamines or other common medications for pruritus [4]. Gabapentin has been used successfully to treat postherpetic pruritus [6]. However, gabapentin does not resolve postherpetic pruritus in all individuals; our patient experienced no relief of the gabapentin that she was taking for her chronic arthritis.

Several other interventions have been used in an attempt to manage this condition (Table 1) [5-6,12-14]. Individual reports described patients whose postherpetic pruritus has been effectively treated with these modalities. Our patient's pruritus was significantly improved after eight weeks of acyclovir. However, some of the therapies, such as those used for postherpetic neuralgia, can actually make the pruritus worse [2]. 


\section{Cureus}

\begin{tabular}{|c|c|c|}
\hline Treatment $^{\mathrm{a}}$ & Comment & Ref \\
\hline Acyclovir & A 57-year-old woman improved with two months of acyclovir. & CR \\
\hline $\begin{array}{l}\text { Amitriptyline } \\
\text { and ketamine } \\
\text { gel }\end{array}$ & $\begin{array}{l}\text { A } 64-y e a r-o l d ~ m a n \text { was initially treated with a variety of medications, including hydrocortisone cream } \\
\text { ( } 2.5 \% \text {, twice daily), dilute acetic acid, gabapentin ( } 400 \mathrm{mg} \text {, three times a day), topical lidocaine } \\
\text { patches, and oral hydroxyzine }(25 \mathrm{mg} \text { daily). These treatments only decreased the patient's pruritus } \\
\text { from } 10 / 10 \text { to } 7-8 / 10 \text { and the duration was less than } 24 \text { hours. Subsequent incorporation of topical } \\
2 \% \text { amitriptyline/ } 0.5 \% \text { ketamine gel resulted in a modest improvement of the pruritus. }\end{array}$ & $\begin{array}{l}\text { Griffin JR } \\
\text { et al. } \\
\text { (2015) }\end{array}$ \\
\hline $\begin{array}{l}\text { Carbamazepine } \\
\text { and } \\
\text { hydroxyzine }\end{array}$ & $\begin{array}{l}\text { A } 22 \text {-year-old man was treated with hydroxyzine }(75 \mathrm{mg} / \mathrm{d}) \text { and carbamazepine }(200 \mathrm{mg} / \mathrm{d} \text { ) for } 3 \text { days. } \\
\text { The pruritus improved from } 10 / 10 \text { to } 7 / 10 \text {. Subsequently, the dose of carbamazepine was increased } \\
\text { to } 400 \mathrm{mg} / \mathrm{d} \text { while the dose of hydroxyzine dose was decreased to } 50 \mathrm{mg} / \mathrm{d} \text { (because of drowsiness). } \\
\text { Two weeks of this treatment regimen completely resolved the patient's pruritus. }\end{array}$ & $\begin{array}{l}\text { Semionov } \\
\text { V et al. } \\
\text { (2008) }\end{array}$ \\
\hline Gabapentin & $\begin{array}{l}\text { A } 40 \text {-year-old woman was started on gabapentin. Three weeks later, the patient reported no } \\
\text { symptoms of pruritus. }\end{array}$ & $\begin{array}{l}\text { Kroshinsky } \\
\text { D et al. } \\
\text { (2011) }\end{array}$ \\
\hline $\begin{array}{l}\text { Pulsed } \\
\text { radiofrequency }\end{array}$ & $\begin{array}{l}\text { A } 56 \text {-year-old man underwent pulsed radiofrequency at the great occipital nerve }\left(37^{\circ} \mathrm{C} \text { for } 120\right. \\
\text { seconds and } 42^{\circ} \mathrm{C} \text { for } 120 \text { seconds). He was also given diprospan }(1 \mathrm{mg}) \text {, vitamin } \mathrm{B} 12(0.5 \mathrm{mg}) \text {, and } \\
\text { lidocaine plain ( }(1 \mathrm{ml} \text { of } 1 \%) \text {. His itching intensity improved from } 5 / 10 \text { to } 1 / 10 \text {, but his pain worsened } \\
\text { from } 2 / 10 \text { to } 5 / 10 \text {. Pulsed radiofrequency was then performed at the great occipital nerve and } \\
\text { supraorbital nerve. The patient was also given gabapentin ( } 300 \mathrm{mg} \text { once a day). At one week follow- } \\
\text { up, patient's pain severity reduced to } 1 / 10 \text {. The gabapentin dosage was lowered to } 200 \mathrm{mg} \text {. At three } \\
\text { weeks follow-up, the patient did not have symptoms and the patient's gabapentin dosage was } \\
\text { reduced further to } 100 \mathrm{mg} \text {. At } 12 \text { weeks follow-up, the patient was asymptomatic. }\end{array}$ & $\begin{array}{l}\text { Ding DF et } \\
\text { al. (2014) }\end{array}$ \\
\hline $\begin{array}{l}\text { Serial stellate } \\
\text { ganglion } \\
\text { blocks with } \\
0.25 \% \\
\text { bupivacaine }\end{array}$ & $\begin{array}{l}\text { A } 10 \text {-year-old man was given two serial stellate ganglion blocks; each dose was } 0.5 \mathrm{~mL} \text { of } 0.25 \% \\
\text { bupivacaine. After recovery, the patient was noted to be free of any itching. Subsequent blocks were } \\
\text { performed on days three and six following the initial procedure. At two weeks follow-up, notable } \\
\text { improvements were seen in the wounds. The patient was maintained on a benzodiazepine and an } \\
\text { antihistamine. Four months later, the patient still had pruritus, but it was noted to have improved } \\
\text { considerably. }\end{array}$ & $\begin{array}{l}\text { Peterson } \\
\text { RC et al. } \\
\text { (2009) }\end{array}$ \\
\hline
\end{tabular}

\section{TABLE 1: Successful treatment options for postherpetic pruritus}

$\mathrm{C}$, centigrade; CR, current report; d, day; ${ }^{\circ}$, degrees; $\mathrm{mg}$, milligrams; $\mathrm{mL}$, milliliters; \%, percent; Ref, reference

[5-6], [12-14]

${ }^{a}$ A 37-year-old man who developed lesions of postherpetic pruritus in the right arm and the upper trunk was unsuccessfully treated with steroid creams, antihistamines, sedatives, analgesics, and carbamazepine. This individual also had pain in his right upper arm prior to the onset of the pruritus. This case demonstrates the potential resistance to treatment that characterizes postherpetic pruritus and neuralgia [15].

Clinicians should conscientiously evaluate pruritus in herpes zoster patients. Itching can have a significant impact on the physical and psychological well-being of these individuals. It can affect the ability of the patient to perform everyday tasks and interact effectively within their social environments [16].

The patient with postherpetic pruritus may continuously scratch the area, particularly if it is desensitized to pain, and create ulcers to the bone [4]. In addition, postherpetic pruritus can affect potential treatment regimens; for example, opioids may not be able to be incorporated into the management of patients with concurrent pruritus and pain following Varicella zoster virus infection. Additional retrospective and prospective studies are warranted to investigate the pathogenesis and potential therapeutic options for postherpetic pruritus.

The cause of our patient's post-herpetic pruritus remains to be established. Perhaps her persistent pruritus was related to a low level of Varicella zoster virus activity due to her chronic immunosuppression. This possibility would account for why she benefited from repeat antiviral therapy.

Herpes zoster is a common viral infection amongst patients with systemic lupus erythematosus, but its exact connection with postherpetic itch is not known [17]. In addition, multiple dermatofibromas have been found in individuals with systemic lupus erythematous or receiving immunosuppressive therapy (such as prednisone) or both [18]. Our patient had systemic lupus erythematous; she also had recurrent episodes of Varicella zoster virus infection and multiple dermatofibromas. 


\section{Conclusions}

Postherpetic pruritus is an uncommon adverse sequela following Varicella zoster infection. It can occur as an isolated event or associated with postherpetic neuralgia. Some patients improve with treatments for postherpetic neuralgia. Indeed, our patient experienced significant improvement of her chronic and persistent postherpetic pruritus after receiving oral acyclovir - at a dosage typically used for acute Varicella zoster infection - for two months.

\section{Additional Information}

\section{Disclosures}

Human subjects: Consent was obtained by all participants in this study. Conflicts of interest: In compliance with the ICMJE uniform disclosure form, all authors declare the following: Payment/services info: All authors have declared that no financial support was received from any organization for the submitted work. Financial relationships: All authors have declared that they have no financial relationships at present or within the previous three years with any organizations that might have an interest in the submitted work. Other relationships: All authors have declared that there are no other relationships or activities that could appear to have influenced the submitted work.

\section{References}

1. Shrestha M, Chen A: Modalities in managing postherpetic neuralgia . Korean J Pain. 2018, 31:235-243. 10.3344/kjp.2018.31.4.235

2. Mittal A, Srivastava A, Balai M, Khare AK: A study of postherpetic pruritus . Indian Dermatol Online J. 2016, 7:343-344. 10.4103/2229-5178.185479

3. Sampathkumar P, Drage LA, Martin DP: Herpes zoster (shingles) and postherpetic neuralgia . Mayo Clin Proc. 2009, 84:274-280.

4. Oaklander AL, Cohen SP, Raju SVY: Intractable postherpetic itch and cutaneous deafferentation after facial shingles. Pain. 2002, 96:9-12. 10.1016/s0304-3959(01)00400-6

5. Semionov V, Shvartzman P: Post herpetic itching--a treatment dilemma. Clin J Pain. 2008, 24:366-368. 10.1097/AJP.0b013e3181633fb1

6. Kroshinsky D, Jagdeo J: A case of post-herpetic itch resolved with gabapentin . J Drugs Dermatol. 2011, 10:85-88.

7. Zografakis C, Tiniakos D, Palaiologou M, Kouloukoussa M, Kittas C, Staurianeas N: Increased density of cutaneous nerve fibres in the affected dermatomes after herpes zoster therapy. Acta Derm Venereol. 2014, 94:168-172. 10.2340/00015555-1664

8. Piccolo V, Baroni A, Russo T, Schwartz RA: Ruocco's immunocompromised cutaneous district. Int J Dermatol. 2016, 55:135-141. 10.1111/ijd.13086

9. Wolf R, Wolf D: "Wolf's isotopic response": the originators speak their mind and set the record straight . Clin Dermatol. 2017, 35:416-418. 10.1016/J.clindermatol.2017.02.003

10. Wolf R, Wolf D, Ruocco E: Wolf's isotopic response: The first attempt to introduce the concept of vulnerable areas in dermatology. Clin Dermatol. 2014, 32:557-560. 10.1016/J.clindermatol.2014.04.002

11. Ruocco E, Brunetti G, Russo T, Gambardella A, Wolf R: Wolf's post-herpetic isotopic response: Infections, tumors, and immune disorders arising on the site of healed herpetic infection. Clin Dermatol. 2014, 32:561568. 10.1016/J.clindermatol.2014.04.003

12. Griffin JR, Davis MDP: Amitriptyline/Ketamine as therapy for neuropathic pruritus and pain secondary to herpes zoster. J Drugs Dermatol. 2015, 14:115-118.

13. Ding DF, Li RC, Xiong QJ, Zhou L, Xiang HB: Pulsed radiofrequency to the great occipital nerve for the treatment of intractable postherpetic itch: a case report. Int J Clin Exp Med. 2014, 7:3497-3500.

14. Peterson RC, Patel L, Cubert K, Gulati A: Serial stellate ganglion blocks for intractable postherpetic itching in a pediatric patient: a case report. Pain Physician. 2009, 12:629-632.

15. Liddell K: Post-herpetic pruritus. Br Med J. 1974, 4:165.

16. Erturk IE, Arican O, Omurlu IK, Sut N: Effect of the pruritus on the quality of life: a preliminary study . Ann Dermatol. 2012, 24:406-412.

17. Chen D, Li H, Xie J, Zhan Z, Liang L, Yang X: Herpes zoster in patients with systemic lupus erythematosus: clinical features, complications and risk factors. Exp Ther Med. 2017, 14:6222-6228. 10.3892/etm.2017.5297

18. Beatrous S V, Riahi RR, Grisoli SB, Cohen PR: Associated conditions in patients with multiple dermatofibromas: case reports and literature review. Dermatol Online J. 2017, 23:13030/qt8zv852d8. 